\title{
Advanced Sulfur Control Concepts in Hot-Gas Desulfurization Technology
}

\author{
Quarterly Report \\ January 1 - March 31, 1998
}

\author{
By: \\ Douglas P. Harrison
}

Work Performed Under Contract No.: DE-AC21-94MC30012

For

U.S. Department of Energy

Office of Fossil Energy

Federal Energy Technology Center

P.O. Box 880

Morgantown, West Virginia 26507-0880

By

Louisiana State University

Department of Chemical Engineering

Baton Rouge, Louisiana 70803

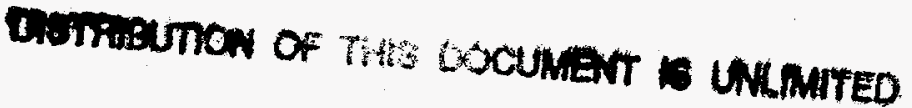




\section{Disclaimer}

This report was prepared as an account of work sponsored by an agency of the United States Government. Neither the United States Government nor any agency thereof, nor any of their employees, makes any warranty, express or implied, or assumes any legal liability or responsibility for the accuracy, completeness, or usefulness of any information, apparatus, product, or process disclosed, or represents that its use would not infringe privately owed rights. Reference herein to any specific commercial product, process, or service by trade name, trademark, manufacturer, or otherwise does not necessarily constitute or imply its endorsement, recommendation, or favoring by the United States Government or any agency thereof. The views and opinions of authors expressed herein do not necessarily state or reflect those of the United States Government or any agency thereof. 


\section{DISCLAIMER}

Portions of this document may be illegible electronic image products. Images are produced from the best available original document. 


\section{EXECUTIVE SUMMARY}

Professor Harrison, project principle investigator, visited Morgantown for a project review in February 1998. Following this review, the project was extended for five months and $\$ 15,000$ in incremental funding was approved. The new project completion date is August 18, 1998.

On the experimental front, the last six cycles of a 25 -cycle sorbent durability test were completed, final installation of the flame photometric detector was accomplished, and fifteen tests whose aim was to determine the minimum prebreakthrough $\mathrm{H}_{2} \mathrm{~S}$ concentration over reduced $\mathrm{CeO}_{2}$ were preformed.

There was a little, if any, evidence of sorbent deterioration in the durability test. For example, the time required for the $\mathrm{H}_{2} \mathrm{~S}$ concentration in the product gas to reach one-half of the feed gas concentration, $\mathrm{t}_{0.5}$, varied only between 97 minutes in cycle 2 and 110 minutes in cycle 17 , with an overall average of 101.2 minutes. There was no apparent deterioration in $t_{0.5}$ as the number of cycles increased. The variation in $t_{0.5}$ for regeneration was also small, ranging from a minimum of 20.6 minutes in cycle 1 to a maximum of 23.0 minutes in cycle 6 . The overall average was 21.9 minutes and again there was no apparent increase with increasing cycle number.

During the durability test we confirmed that, when using pre-reduced sorbent and a clean system, the prebreakthrough $\mathrm{H}_{2} \mathrm{~S}$ concentration was less than $\sim 100 \mathrm{ppmv}$, the detection limit of the thermal conductivity detector (TCD). Consequently, a more sensitive flame photometric detector (FPD) which permitted measurements of $\mathrm{H}_{2} \mathrm{~S}$ concentrations of $1 \mathrm{ppmv}$ or less was installed. The FPD and TCD were connected in parallel so that, when desired, the entire $\mathrm{H}_{2} \mathrm{~S}$ breakthrough curve could be measured.

Most of the quarter was devoted to conducting reduction-sulfidation tests to determine the minimum prebreakthrough $\mathrm{H}_{2} \mathrm{~S}$ concentrations which could be achieved using prereduced $\mathrm{CeO}_{2}$. Fifteen runs involving variations in reduction -sulfidation temperature, $\mathrm{H}_{2} \mathrm{~S}$ concentration in the feed gas, and feed gas volumetric flow rate were completed. In all tests the prebreakthrough $\mathrm{H}_{2} \mathrm{~S}$ concentration was less than $10 \mathrm{ppmv}$, and in many of the tests the $\mathrm{H}_{2} \mathrm{~S}$ concentration was equal to or less than lppmv for an extended time period.

\section{SORBENT DURABILITY TEST}

The last six cycles of a twenty-five cycle sorbent durability test were completed in January. The initial sorbent charge consisted of $6 \mathrm{~g}$ Rhone Poulenc $\mathrm{CeO}_{2}$ mixed with $3 \mathrm{~g} \mathrm{Al}_{2} \mathrm{O}_{3}$. Reaction conditions were as follows:

1. Reduction at $800^{\circ} \mathrm{C}$ and $5 \mathrm{~atm}$. In cycles 1 through 15 the reduction gas contained $10 \%$ $\mathrm{H}_{2}$ in $\mathrm{N}_{2}$ at a flow rate of $400 \mathrm{sccm}$. In the remaining cycles reduction was carried out in $100 \% \mathrm{H}_{2}$ at a flow rate of $50 \mathrm{sccm}$. The reduction was generally carried out overnight. 
2. Sulfidation at $800^{\circ} \mathrm{C}$ and 5 atm in $1 \% \mathrm{H}_{2} \mathrm{~S} / 10 \% \mathrm{H}_{2} / \mathrm{N}_{2}$ at a rate of $400 \mathrm{sccm}$. Each sulfidation cycle was continued until $\mathrm{H}_{2} \mathrm{~S}$ breakthrough was complete, typically about 2 hours.

3. Regeneration at $600^{\circ} \mathrm{C}$ and 1 atm in $12 \% \mathrm{SO}_{2} / \mathrm{N}_{2}$ at a rate of $200 \mathrm{sccm}$. Regeneration was continued until the $\mathrm{SO}_{2}$ content of the product gas reached $12 \%$, typically about 30 minutes.

4. Reactor cleaning at $800^{\circ} \mathrm{C}$ and $5 \mathrm{~atm}$ using air at $50 \mathrm{sccm}$. The purpose of this oxidation step was to remove, to the extent possible, all elemental sulfur deposited downstream of the sorbent bed during regeneration. As further precaution against contamination, different reactor exit lines were used during sulfidation and regeneration. During sulfidation the product gas flowed through teflon-lined tubing and a $7 \mu$ stainless steel filter to the back pressure regulator and then through teflon tubing to the stainless steel chromatograph sampling valve. Stainless steel in contact with the sulfidation product gas consisted of three fittings, one filter, the back pressure regulator, the chromatograph sampling valve, and the TCD housing. During regeneration the product gas flowed through heat-traced stainless steel lines to the condenser and then through a series of filters and stainless steel tubing to the sampling valve. The back pressure regulator was not used during the atmospheric pressure regeneration tests and the only stainless steel parts exposed to both sulfidation and regeneration product gases were one fitting, the sampling valve, and the TCD housing.

Complete $\mathrm{H}_{2} \mathrm{~S}$ breakthrough curves for the 25 cycles are shown in Figure 1. Results of a nonreacting $\mathrm{H}_{2} \mathrm{~S}$ tracer tests at the same conditions are included for comparison. All concentrationtime curves were similar except for the following exceptions.

In the 20 to 90 minute range the $\mathrm{H}_{2} \mathrm{~S}$ concentration from cycle 01 was clearly larger than from any of the remaining cycles. In the same time range the $\mathrm{H}_{2} \mathrm{~S}$ concentrations in cycles 02 through 15 are closely bunched at an intermediate level, while in cycles 16 through $25 \mathrm{H}_{2} \mathrm{~S}$ concentration was below the TCD detection limit for about 80 minutes. These features are more clearly shown in Figure 2 where the concentration scale is expanded to emphasize results during the early reaction times. The improvement between cycles 15 and 16 is clearly due to the switch from $10 \% \mathrm{H}_{2}$ to $100 \% \mathrm{H}_{2}$ during the reduction step. The delayed breakthrough in cycle 16, which is particularly evident in Figure 1, is attributed to reduced $\mathrm{H}_{2} \mathrm{~S}$ feed rate caused by mass flow controller malfunction.

The time required for the product $\mathrm{H}_{2} \mathrm{~S}$ concentration to reach $0.5 \%$ (one-half of the feed concentration), $t_{0.5}$, provides a good comparison of sulfidation reproducibility during the active breakthrough stage. Figure 3 shows $t_{0.5}$ versus cycle number for the twenty-five cycles, excluding cycle 16 because of the mass flow controller problems. $t_{0.5}$ ranged from a minimum of 97 minutes in cycle 2 to a maximum of 110 minutes in cycle 17. The twenty-four-cycle average was 101.2 minutes and there was no indication of a decrease in $t_{0.5}$ with increasing cycle number.

Combining the $\mathrm{H}_{2} \mathrm{~S}$ breakthrough curves with the nonreacting tracer results shown in Figure 1 made it possible to estimate the overall percent conversion of $\mathrm{CeO}_{2}$ to $\mathrm{Ce}_{2} \mathrm{O}_{2} \mathrm{~S}$ at the conclusion of each cycle. These results are presented in Figure 4. The smallest value of $95 \%$ conversion occurred in cycle 01 while the largest value of $116 \%$ occurred in cycle 16 . If this value 


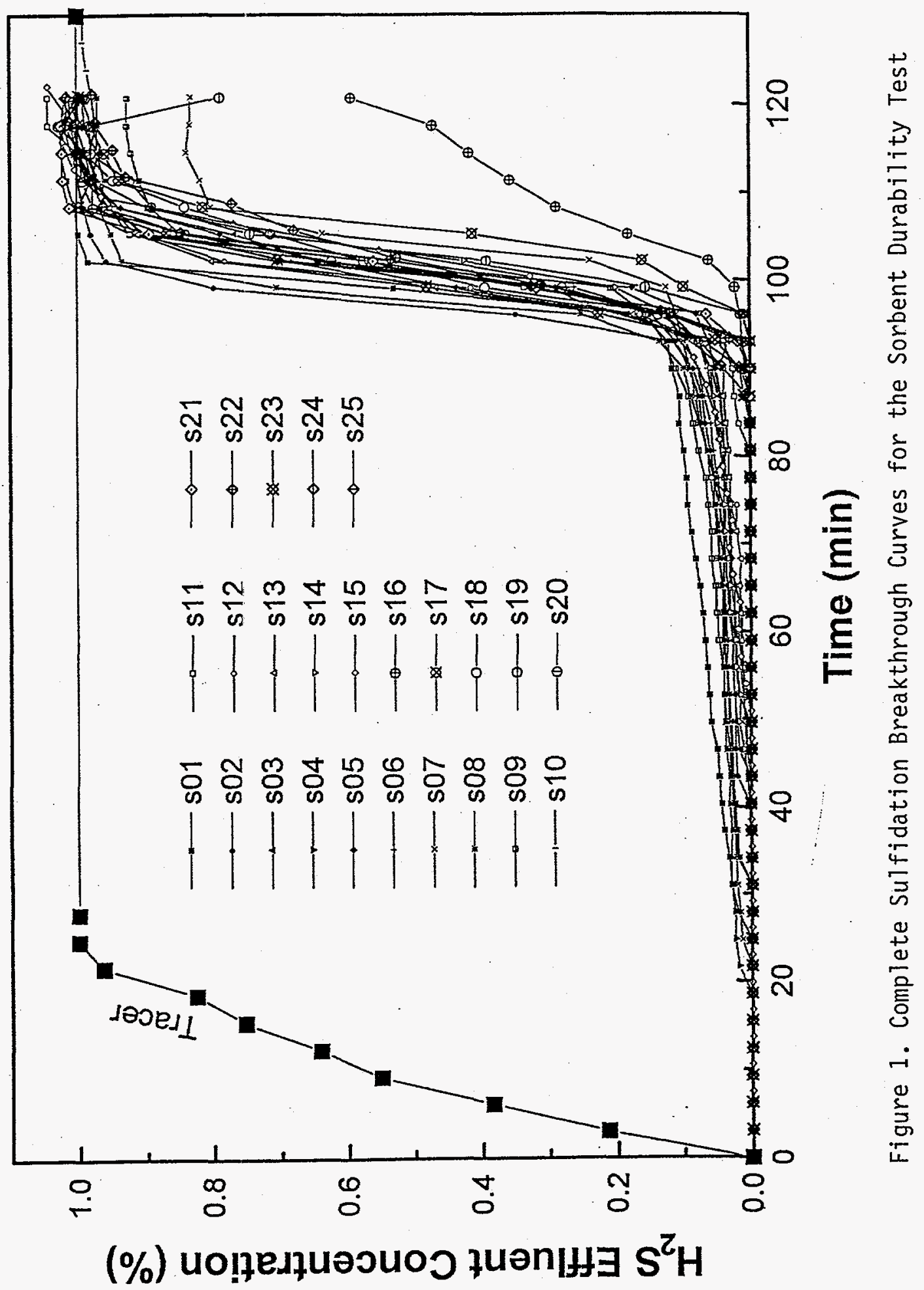




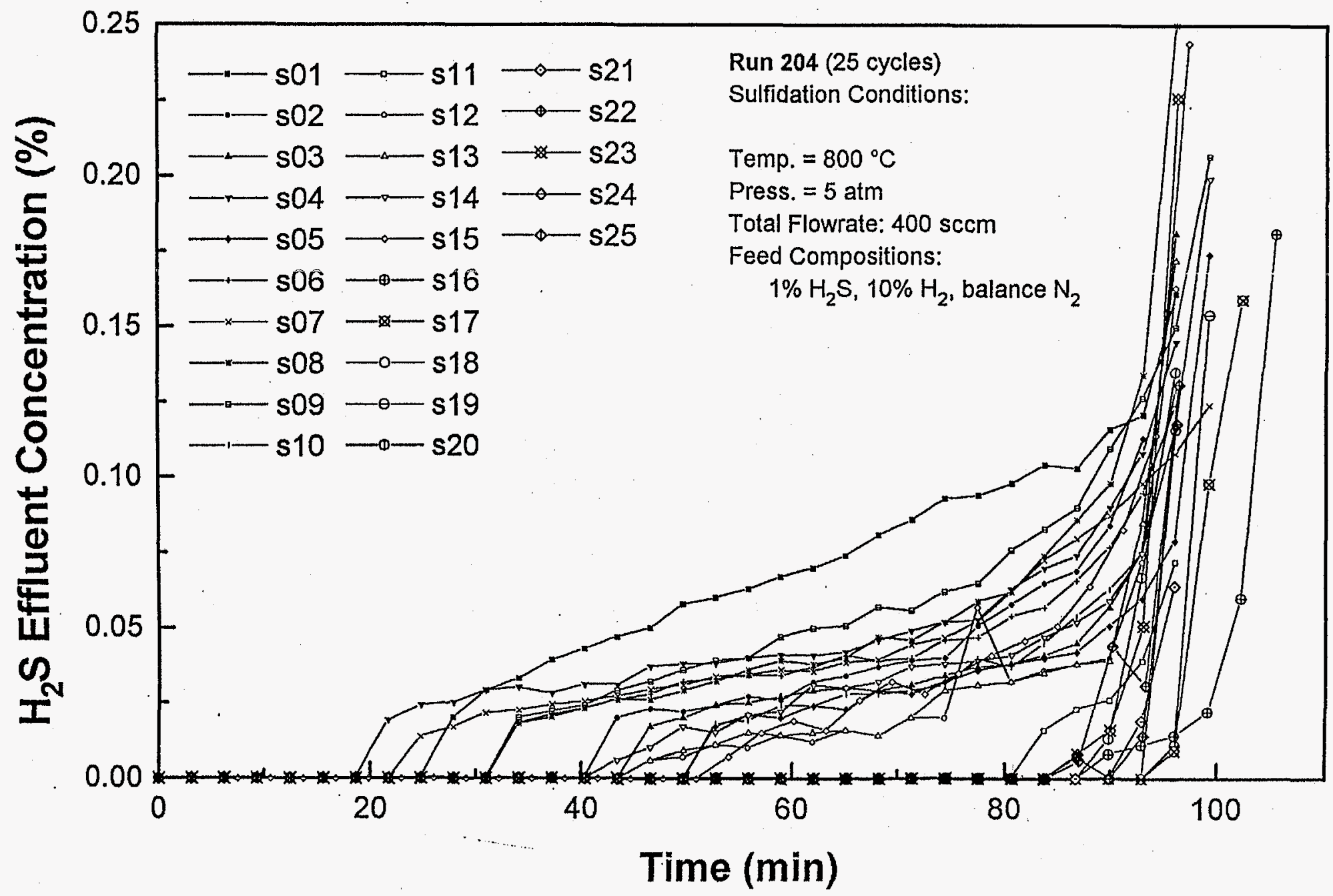

Figure 2. Early Portions of the Sulfidation Breakthrough Curves in the Sorbent Durability Test 







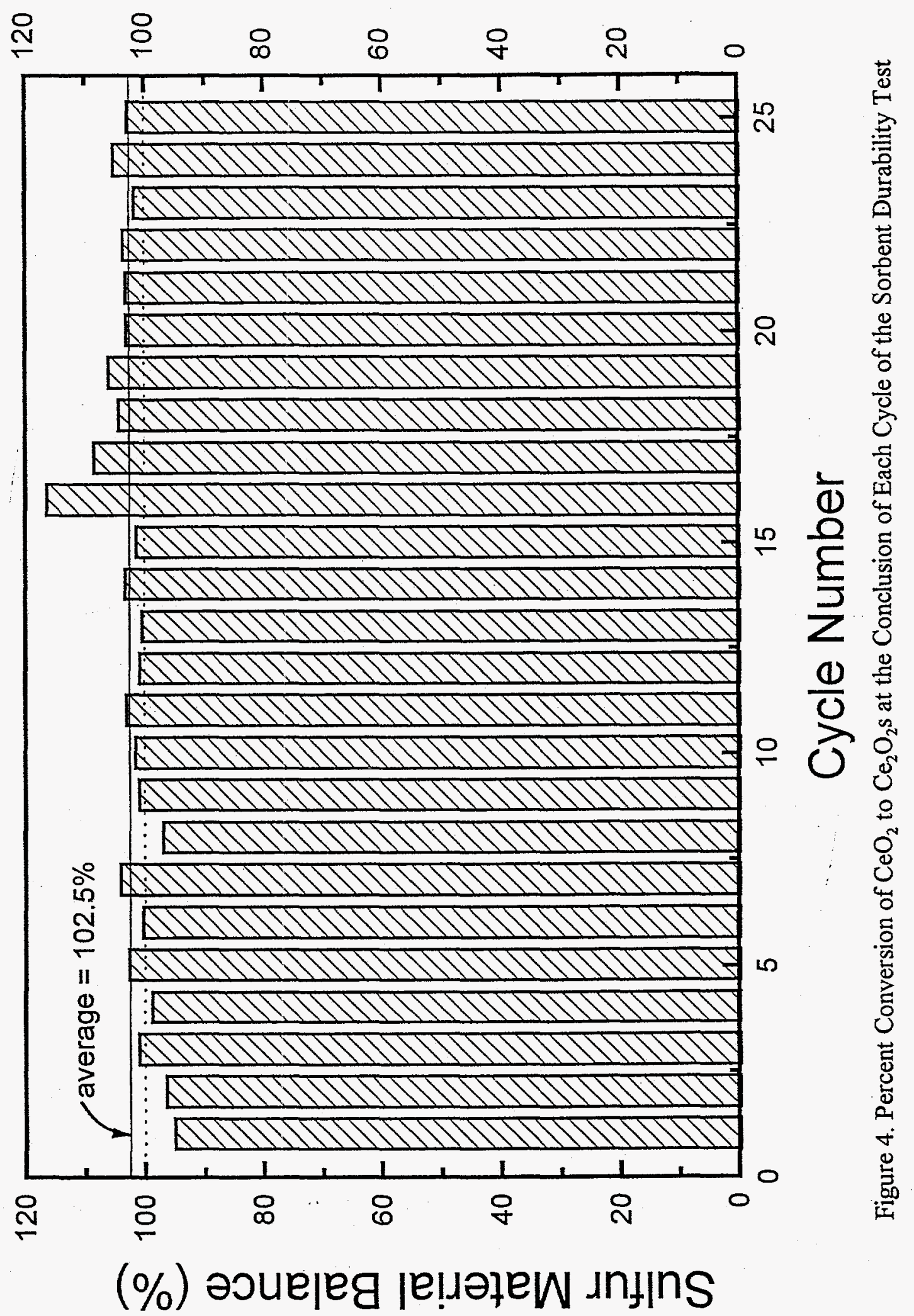


is excluded because of the previously mentioned mass flow controller problems, the maximum of $108 \%$ conversion occurred in cycle 17 . The twenty-five-cycle average (including cycle 16) was $102.5 \%$. These conversion calculations are based on a loss of $9 \%$ of the $\mathrm{CeO}_{2}$ charge due to formation of volatiles during the heating period. This $9 \%$ loss was measured in previous electrobalance tests.

Regeneration conditions were constant in all cycles and Figure 5 shows that the $\mathrm{SO}_{2}$ breakthrough curves were also quite similar. Results from a nonreacting $\mathrm{SO}_{2}$ tracer test are also included for comparison. Regeneration results from cycle 08 are omitted because of elemental sulfur plugging problems. Complete regeneration was achieved, however, as shown by the cycle 09 sulfidation results. Plugging also occurred near the end of cycles 06 and10, but the regeneration breakthrough curves were effectively' complete before the problem occurred.

$\mathrm{t}_{0.5}$ corresponding to $6 \% \mathrm{SO}_{2}$ in the regeneration product gas ( $50 \%$ of the feed concentration) is shown for each regeneration cycle in Figure 6. Results from cycle 08 are omitted. During regeneration, $\mathrm{t}_{0.5}$ varied from a minimum of 20.6 minutes in cycle 01 to a maximum of 23.0 minutes in cycle 06 . The twenty-four cycle average was 21.9 minutes and, once again, these was no evidence of performance deterioration in the latter cycles.

Percent conversion of $\mathrm{Ce}_{2} \mathrm{O}_{2} \mathrm{~S}$ to $\mathrm{CeO}_{2}$ for each cycle based on the $\mathrm{SO}_{2}$ breakthrough curves and the nonreacting tracer test are shown in Figure 7. Results ranged from a low of $91 \%$ in cycle 05 to a high of $109 \%$ in cycle 06 with a twenty-four cycle average of $98.3 \%$. The scatter in the regeneration results is somewhat larger than in sulfidation because only 9 or 10 data points collected during a regeneration cycle compared to about 40 data points during sulfidation. Nevertheless, the average of $98.3 \%$ for regeneration compared to $102.5 \%$ for sulfidation is felt to be quite good.

During the entire fifty-eight day duration of the durability test, the sorbent was continually exposed to a temperature of at least $600^{\circ} \mathrm{C}$ with the temperature being $800^{\circ} \mathrm{C}$ for approximately $90 \%$ of that time. During that time the sorbent was alternately exposed to $\mathrm{H}_{2} / \mathrm{N}_{2}$ during reduction, $\mathrm{H}_{2} \mathrm{~S} / \mathrm{H}_{2} / \mathrm{N}_{2}$ during sulfidation, $\mathrm{SO}_{2} / \mathrm{N}_{2}$ during regeneration, air during cleaning, and $\mathrm{N}_{2}$ purge between each phase. The durability of the sorbent is judged to be exceptionally good.

\section{FLAME PHOTOMETRIC DETECTOR (FPD)}

The ability to reduce $\mathrm{H}_{2} \mathrm{~S}$ concentrations during the prebreakthrough period to below the TCD detection limit led to installation of a FPD having a detection limit of about $1 \mathrm{ppmv}$. A great deal of trial-and-error experimentation was required before $\mathrm{H}_{2} \mathrm{~S}$ concentrations near the 1 ppmv level could be reliably measured. For example, the reactor and product lines downstream of the sorbent bed had to be free of residual sulfur. $\mathrm{H}_{2} \mathrm{~S}$ produced by the reaction between $\mathrm{H}_{2}$ and contaminant sulfur could easily exceed the $\mathrm{H}_{2} \mathrm{~S}$ in the product gas. Stainless steel parts in contact with the product gas were minimized as described in the previous section. We also found the system would not operate reliably with the two detectors arranged in series with the TCD followed by the FPD. The 


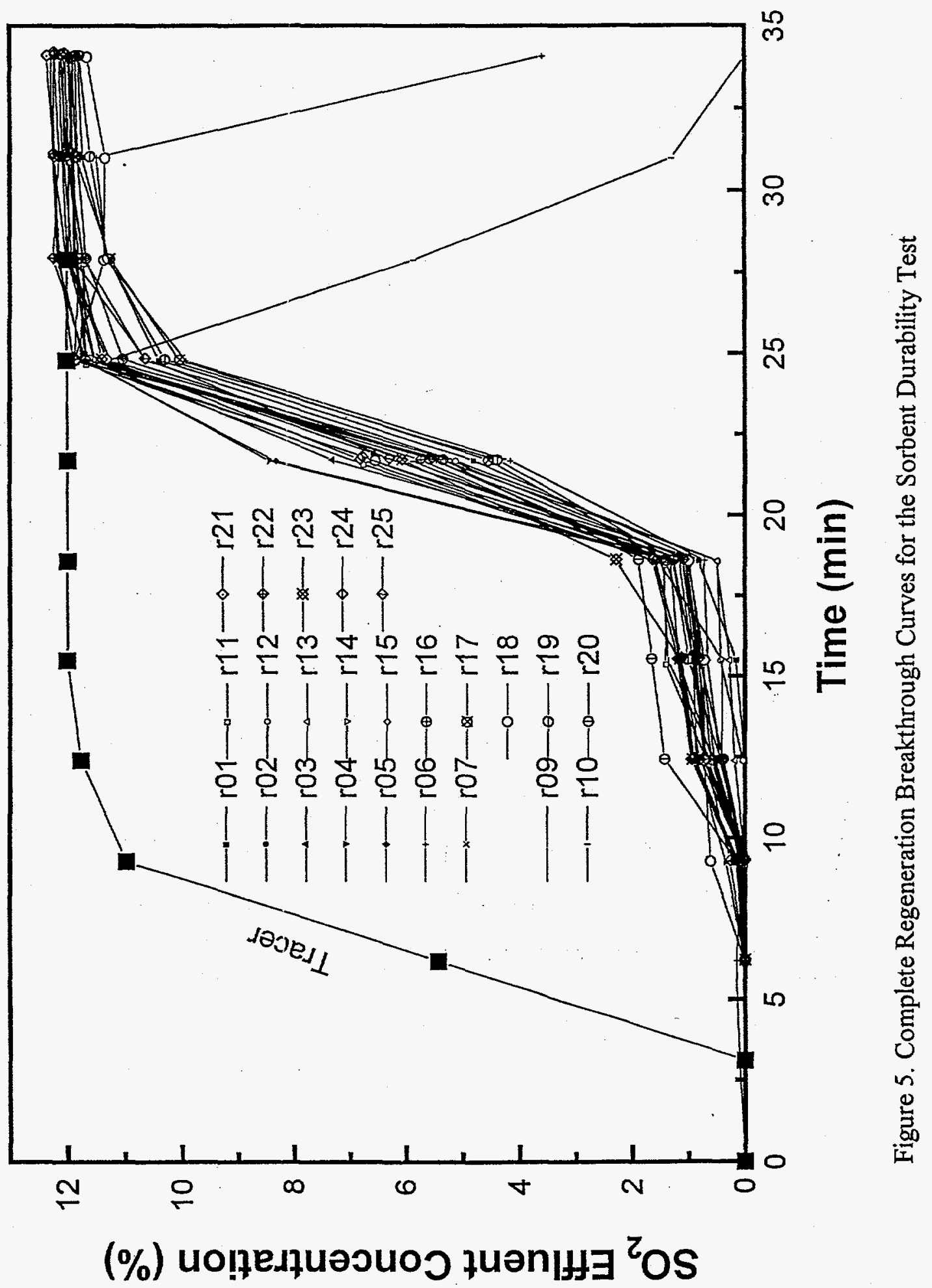




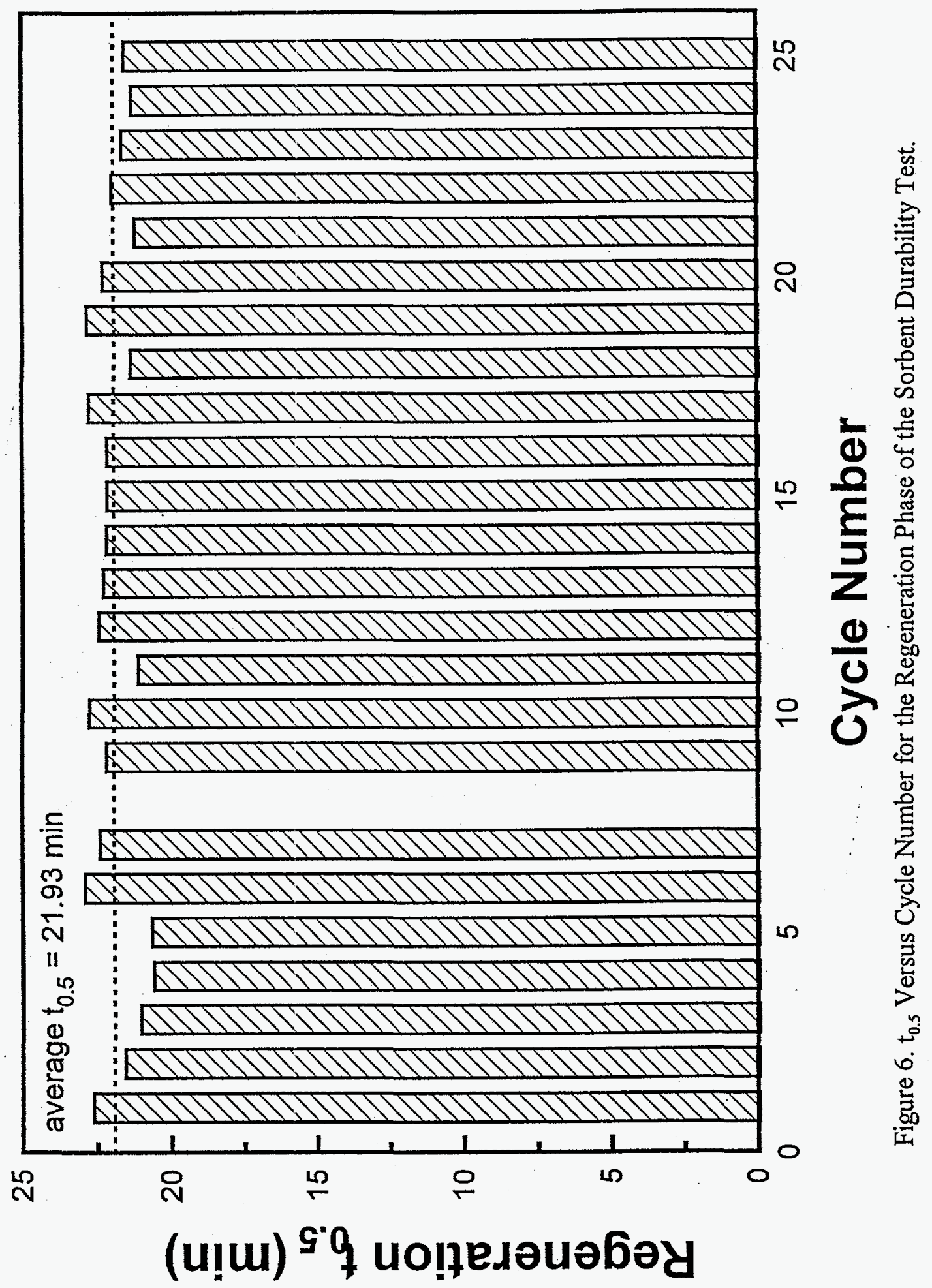




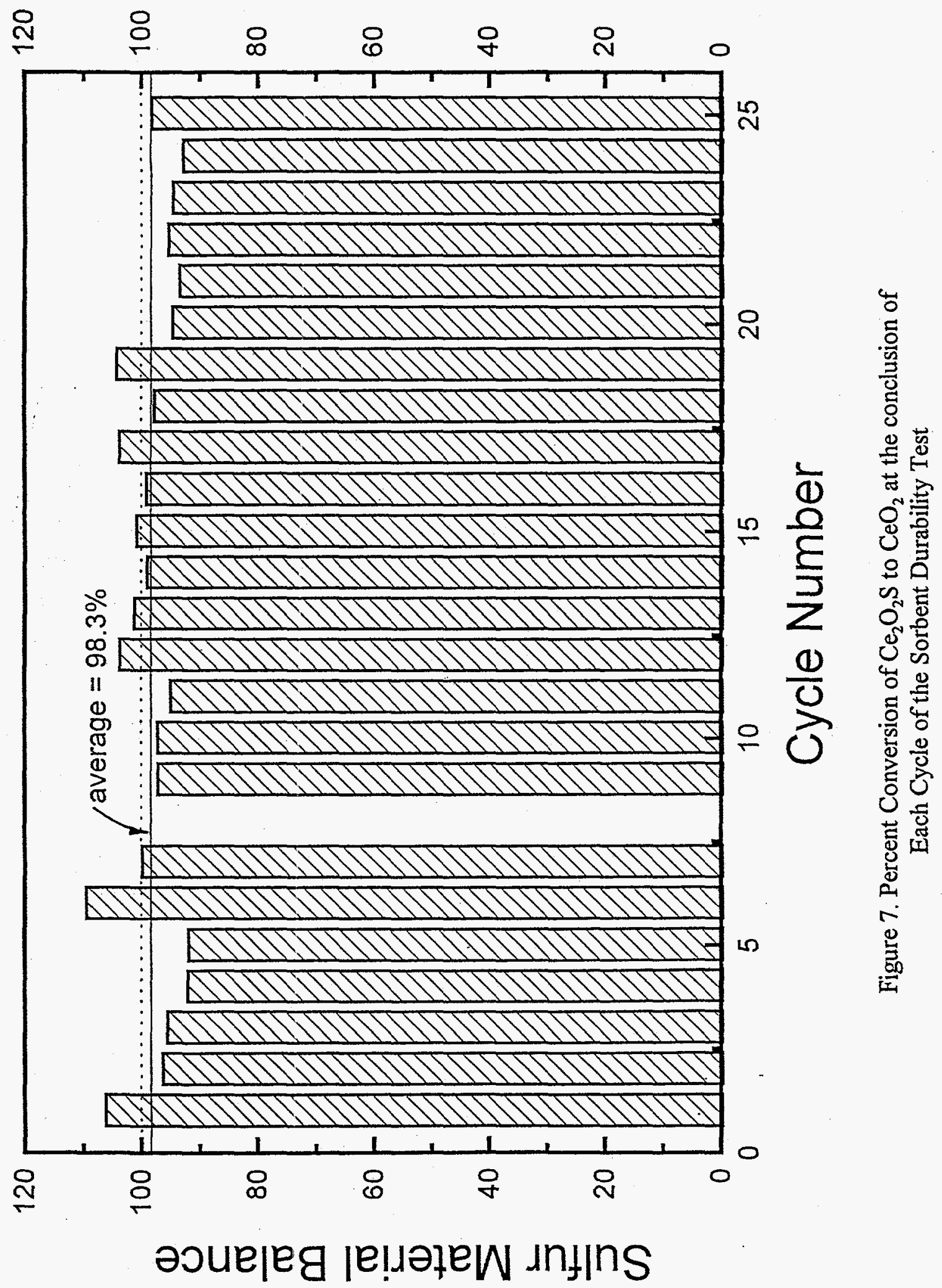


problem was determined to be caused by adsorption/desorption of $\mathrm{H}_{2} \mathrm{~S}$ on the stainless steel surface of the TCD.

A parallel arrangement of the detectors as shown in Figure 8 was finally implemented. Column 2 effluent flows into a remotely actuated three-way solenoid valve which, during the early prebreakthrough period, directs the product to the FPD. When the $\mathrm{H}_{2} \mathrm{~S}$ content increases to the FPD saturation level, the solenoid valve is switched and product is directed to the TCD. No additional stainless steel is introduced as all wetted parts of the solenoid valve are of teflon.

Alteration in the analytical system required that both detectors be recalibrated. In addition to installing the solenoid valve and parallel detectors, the volume of the sample loop and the carrier gas flow rate were changed to provide reasonable operating conditions for both detectors. As usual, the TCD calibration for both $\mathrm{H}_{2} \mathrm{~S}$ and $\mathrm{SO}_{2}$ was linear through the origin. The equations relating concentration and area are:

$$
\begin{gathered}
\text { ppmv } \mathrm{H}_{2} \mathrm{~S}=1.287 \times 10^{-1} \text { Area } \\
\% \mathrm{SO}_{2}=5.136 \times 10^{-5} \text { Area }
\end{gathered}
$$

The FPD response to $\mathrm{H}_{2} \mathrm{~S}$ was quadratic and separate equations were determined for low $\mathrm{H}_{2} \mathrm{~S}$ concentrations ( 0 to $3 \mathrm{ppmv}$ ), medium $\mathrm{H}_{2} \mathrm{~S}$ concentrations ( 3 to $15 \mathrm{ppmv}$ ) and high $\mathrm{H}_{2} \mathrm{~S}$ concentrations (15-108 ppmv). The quadratic equations are:

$$
\begin{aligned}
& \text { ppmv } \mathrm{H}_{2} \mathrm{~S}=0.0612\left[(1+5.444 \text { Area })^{1 / 2}-1\right] \\
& \text { for } 1 \leq p p m v \mathrm{H}_{2} \mathrm{~S} \leq 3 \\
& \text { ppmv } \mathrm{H}_{2} \mathrm{~S}=0.206\left[(1+0.402 \text { Area })^{1 / 2}+1\right] \\
& \text { for } 3 \leq \text { ppmv } \mathrm{H}_{2} \mathrm{~S} \leq 15 \\
& \text { ppmv } \mathrm{H}_{2} \mathrm{~S}=6.942\left[(1+0.000577 \text { Area })^{1 / 2}-1\right] \\
& \text { for } 15 \leq \text { ppmv } \mathrm{H}_{2} \mathrm{~S} \leq 108
\end{aligned}
$$

Once again the minimum $\mathrm{H}_{2} \mathrm{~S}$ detection limit for the TCD was near 100 ppmv while the maximum and minimum detection limits of the FPD were near 100 ppmv and 1 ppmv, respectively.

Results of the first reduction-sulfidation test $(\mathrm{Ce} 205 \mathrm{~s} 01)$ using the two detectors in parallel are shown in Figure 9. The standard $\mathrm{CeO}_{2}-\mathrm{Al}_{2} \mathrm{O}_{3}$ mixture was prereduced at $800^{\circ} \mathrm{C}$ and $5 \mathrm{~atm}$ in $10 \%$ $\mathrm{H}_{2} / \mathrm{N}_{2}$ overnight. Sulfidation was then carried out $800^{\circ} \mathrm{C}$ and 5 atm using $1 \% \mathrm{H}_{2} \mathrm{~S} / 10 \% \mathrm{H}_{2} / \mathrm{N}_{2} . \mathrm{H}_{2} \mathrm{~S}$ concentration is plotted on a logarithmic scale so that the entire concentration range from $<10 \mathrm{ppmv}$ to 10,000 ppmv $(1 \%)$ is clearly visible. The product gas $\mathrm{H}_{2} \mathrm{~S}$ concentration was below $10 \mathrm{ppmv}$, corresponding to $99.9 \% \mathrm{H}_{2} \mathrm{~S}$ removal, for the first 35 minutes and then increased gradually to 100 


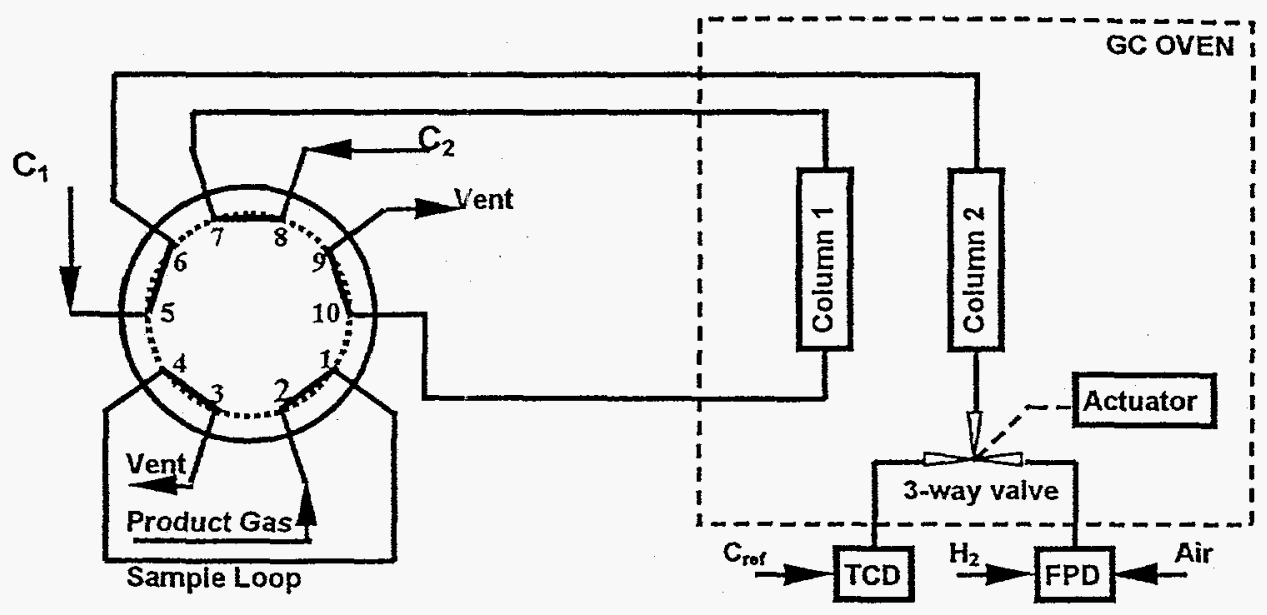

(a) GC Operation - Step One

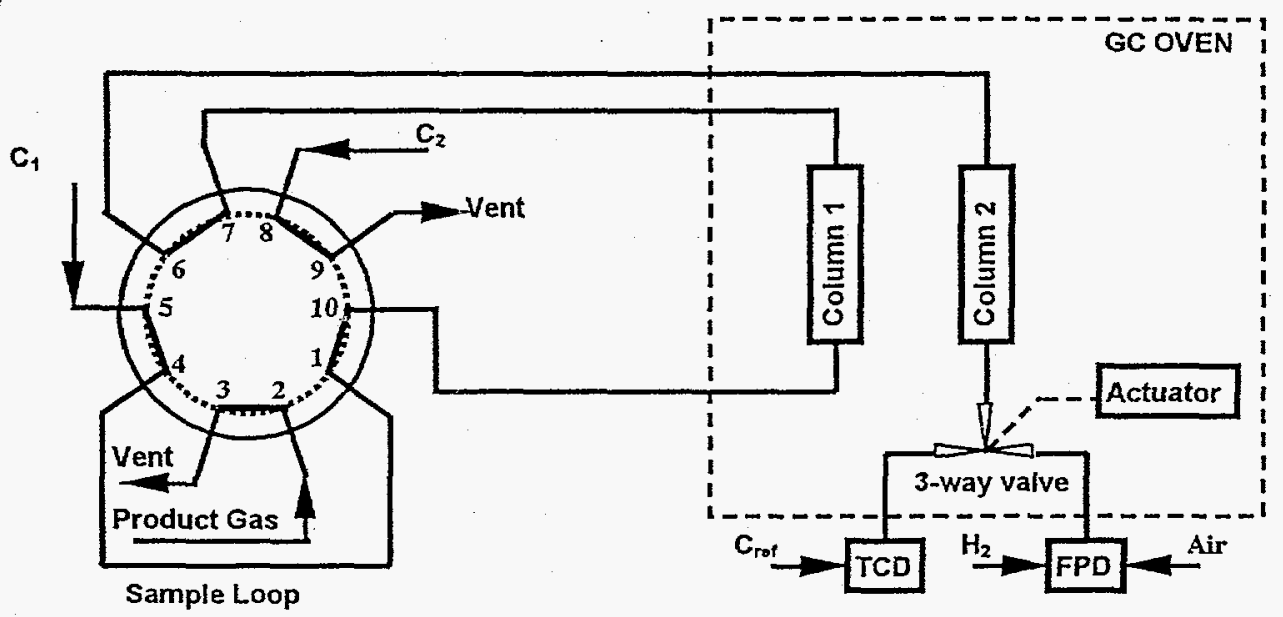

(b) GC Operation - Step Two

Actuator: $115 \mathrm{~V}$ Solenoid

$\mathrm{C}_{1}, \mathrm{C}_{2}, \mathrm{C}_{\text {rot: }}$ Carrier gases (Helium)

Column 1: Water trap column (PORAPAK Q)

Column 2: Separation column (CHROMOSIL 310)

Figure 8. Parallel Arrangement of the FPD and TCD Detectors 


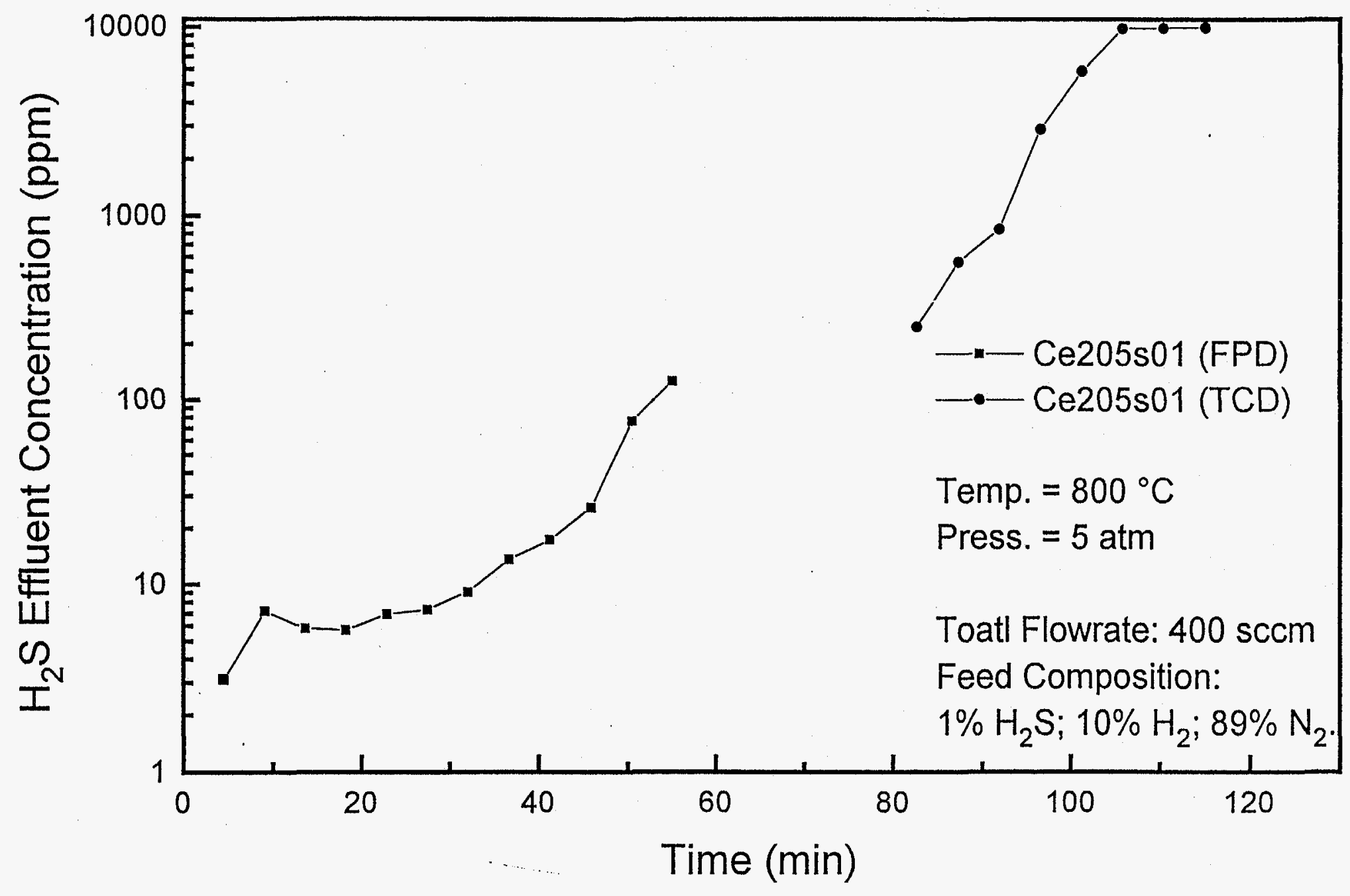

Figure 9. Results of the First Sulfidation Test (Ce205s01) Using the Parallel Arrangement of the FPD and TCD 
ppmv after about 50 minutes. At that time the three-way solenoid valve was switched to send product gas to the TCD. The TCD cannot operate while flow is directed to the FPD and the 30 minute gap in the data was necessary to allow the TCD to warm-up and stabilize after being turned on. The $\mathrm{H}_{2} \mathrm{~S}$ concentration from the first TCD sample at 83 minutes was about $250 \mathrm{ppmv}$, and by 106 minutes the $\mathrm{H}_{2} \mathrm{~S}$ concentration increased to near the feed value of 10,000 ppmv (1\%).

The results from this test are in general agreement with results from succeeding runs discussed in the next section except that the FPD breakthrough (in the 30 to 60 minute time range) was more gradual than in the succeeding runs. As will be shown, the more normal response was for the $\mathrm{H}_{2} \mathrm{~S}$ concentration to increase from about $10 \mathrm{ppmv}$ to greater than $100 \mathrm{ppmv}$ in a single sample interval. The reason for this difference is not known.

\section{REDUCTION-SULFIDATION TEST RESULTS}

A total of 15 reduction-sulfidation tests (including Ce205s01) were completed using the FPD and, in some cases the FPD-TCD, for product analysis. Reaction conditions for the tests are summarized in Table 1. The standard reactor charge of $6.00 \mathrm{~g}$ Rhone Poulenc $\mathrm{C}_{2} \mathrm{O}_{2}$ and $3.0 \mathrm{~g} \mathrm{Al}_{2} \mathrm{O}_{3}$ was used in all tests. The reduction gas composition was constant at $10 \% \mathrm{H}_{2}$ in $\mathrm{N}_{2}$ and reduction and sulfidation pressures were constant at $5 \mathrm{~atm}$. Reaction parameters investigated were reductionsulfidation temperature $\left(600\right.$ to $\left.850^{\circ} \mathrm{C}\right)$, sulfidation feed gas composition $(0.25 \%$ and $1.0 \%$ in $10 \%$ $\mathrm{H}_{2} / \mathrm{N}_{2}$ ), and sulfidation gas feed rate $(200$ to $800 \mathrm{sccm}$ ). The sorbent was pre-reduced in all tests except $\mathrm{Ce} 13 \mathrm{~s} 01 . \mathrm{H}_{2} \mathrm{~S}$ removal in that test was considerably smaller than in test $\mathrm{Ce} 210 \mathrm{~s} 01$ at equivalent reaction conditions and with pre-reduction. No regeneration tests were carried out in order to minimize sulfur contamination of the reactor system.

Duplicate Test Results

Test $\mathrm{Ce} 205 \mathrm{~s} 01, \mathrm{Ce} 2 \mathrm{~s} 06 \mathrm{~s} 01$, and $\mathrm{Ce} 207 \mathrm{~s} 01$ used identical reaction conditions except that $\mathrm{Ce} 207 \mathrm{~s} 01$ was terminated immediately after the product $\mathrm{H}_{2} \mathrm{~S}$ concentration exceeded the FPD saturation value ( $100 \mathrm{ppmv})$. In both $\mathrm{Ce} 205 \mathrm{~s} 01$ and $\mathrm{Ce} 206 \mathrm{~s} 01$ product gas flow was shifted to the TCD after FPD saturation so that the entire breakthrough curve was obtained.

$\mathrm{H}_{2} \mathrm{~S}$ concentrations from the first 30 minutes of the three tests are compared in Figure 10. The $\mathrm{H}_{2} \mathrm{~S}$ concentration is presented on a linear scale and is limited to $20 \mathrm{ppmv}$. All early concentrations were in the range of 3 to $8 \mathrm{ppmv}$ (corresponding to 99.92 to $99.97 \% \mathrm{H}_{2} \mathrm{~S}$ removal). However, there were significant differences after 20 minutes. In Ce206s 01 the $\mathrm{H}_{2} \mathrm{~S}$ concentration increased between the fifth and sixth samples ( 22 and 28 minutes) from 5 ppmv to greater than 100 ppmv. A similar increase from $3 \mathrm{ppmv}$ to greater than $100 \mathrm{ppmv}$ occurred in $\mathrm{Ce} 207 \mathrm{~s} 01$ between the sixth and seventh samples ( 28 to 34 minutes). In contrast, the $\mathrm{H}_{2} \mathrm{~S}$ concentration in $\mathrm{Ce} 20501$ increased gradually and remained below 100 ppmv for 50 minutes (see Figure 9). However, as previously stated, the sharp increase observed in Ce206s01 and Ce207s01 is more common. 
Table 1. Summary of Reduction - Sulfidation Reaction Conditions (January - March 1998)

\begin{tabular}{|c|c|c|c|c|c|c|c|c|c|c|c|c|c|c|c|}
\hline Test & Ce205sa & $\mathrm{Ce} 206 \mathrm{~s} 0$ & $\mathrm{Ce} 207 \mathrm{sO}$ & Ce208so & $\mathrm{Ce} 209_{s 0}$ & $\mathrm{Ce} 210 \mathrm{~s} 0$ & Ce211so & $\mathrm{Ce} 212 \mathrm{~s} 0$ & $\mathrm{Ce} 213 s 0$ & $\mathrm{Ce} 214 \mathrm{~s} 0$ & $\mathrm{Ce} 215 \mathrm{~s} 0$ & Ce216so & Ce217s0 & $\operatorname{Ce} 218 \mathrm{~s} 0$ & $\mathrm{Ce} 219 \mathrm{~s} 01$ \\
\hline Date & 1 & 1 & 1 & 1 & 1 & 1 & 1 & 1 & 1 & 1 & 1 & 1 & 1 & 1 & $130 / 98$ \\
\hline & & $2 / 02 / 98$ & $2 / 03 / 98$ & $2 / 06 / 98$ & $2 / 10 / 98$ & $2 / 13 / 98$ & $2 / 17 / 98$ & $2 / 19 / 98$ & $2 / 22 / 98$ & $2 / 23 / 98$ & $3 / 05 / 98$ & $3 / 18 / 98$ & $3 / 23 / 98$ & $3 / 27 / 98$ & \\
\hline
\end{tabular}

Sorbent

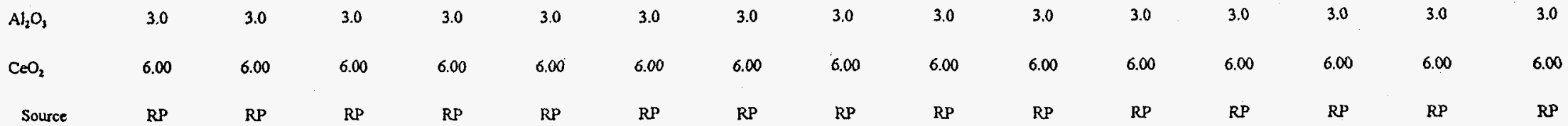

Reduction

\begin{tabular}{|c|c|c|c|c|c|c|c|c|c|c|c|c|c|c|}
\hline Temp., ${ }^{\circ} \mathrm{C}$ & 800 & 800 & 800 & 850 & 750 & 700 & 650 & 600 & - & 700 & 700 & 700 & 700 & 700 \\
\hline Press., alm & 5 & 5 & 5 & 5 & 5 & 5 & 5 & 5 & - & 5 & 5 & $s$ & 5 & 5 \\
\hline
\end{tabular}

Gas Comp.

$\begin{array}{lllllllllllllllll}\% \mathrm{H}_{2} & 10 & 10 & 10 & 10 & 10 & 10 & 10 & 10 & - & 10 & 10 & 10 & 10 & 10 & 10 & \\ \% \mathrm{~N}_{2} & 90 & 90 & 90 & 90 & 90 & 90 & 90 & 90 & - & 90 & 90 & 90 & 90 & 90 & 90\end{array}$

Sulfidation

\begin{tabular}{|c|c|c|c|c|c|c|c|c|c|c|c|c|c|c|c|}
\hline Temp., ${ }^{\circ} \mathrm{C}$ & 800 & 800 & 800 & 850 & 750 & 700 & 650 & 600 & 700 & 700 & 700 & 700 & 700 & 700 & 700 \\
\hline Press., atm & 5 & 5 & 5 & 5 & 5 & 5 & 5 & 5 & 5 & 5 & 5 & 5 & 5 & 5 & 5 \\
\hline \multicolumn{16}{|l|}{ Gas Comp. } \\
\hline$\% \mathrm{H}_{2} \mathrm{~S}$ & 1 & 1 & 1 & 1 & 1 & 1 & 1 & 1 & 1 & 0.25 & 0.25 & 1.0 & 1.0 & 0.25 & 0.25 \\
\hline$\% \mathrm{H}_{2}$ & 10 & 10 & 10 & 10 & 10 & 10 & 10 & 10 & 10 & 10 & 10 & 10 & 10 & 10 & 10 \\
\hline$\% \mathrm{~N}_{2}$ & 89 & 89 & 89 & 89 & 89 & 89 & 89 & 89 & 89 & 89.75 & 89.75 & 89 & 89 & 89.75 & 89.75 \\
\hline Flow Rate, & 400 & 400 & 400 & 400 & 400 & 400 & 400 & 400 & 400 & 400 & 400 & 200 & 800 & 200 & 800 \\
\hline
\end{tabular}

sccm 


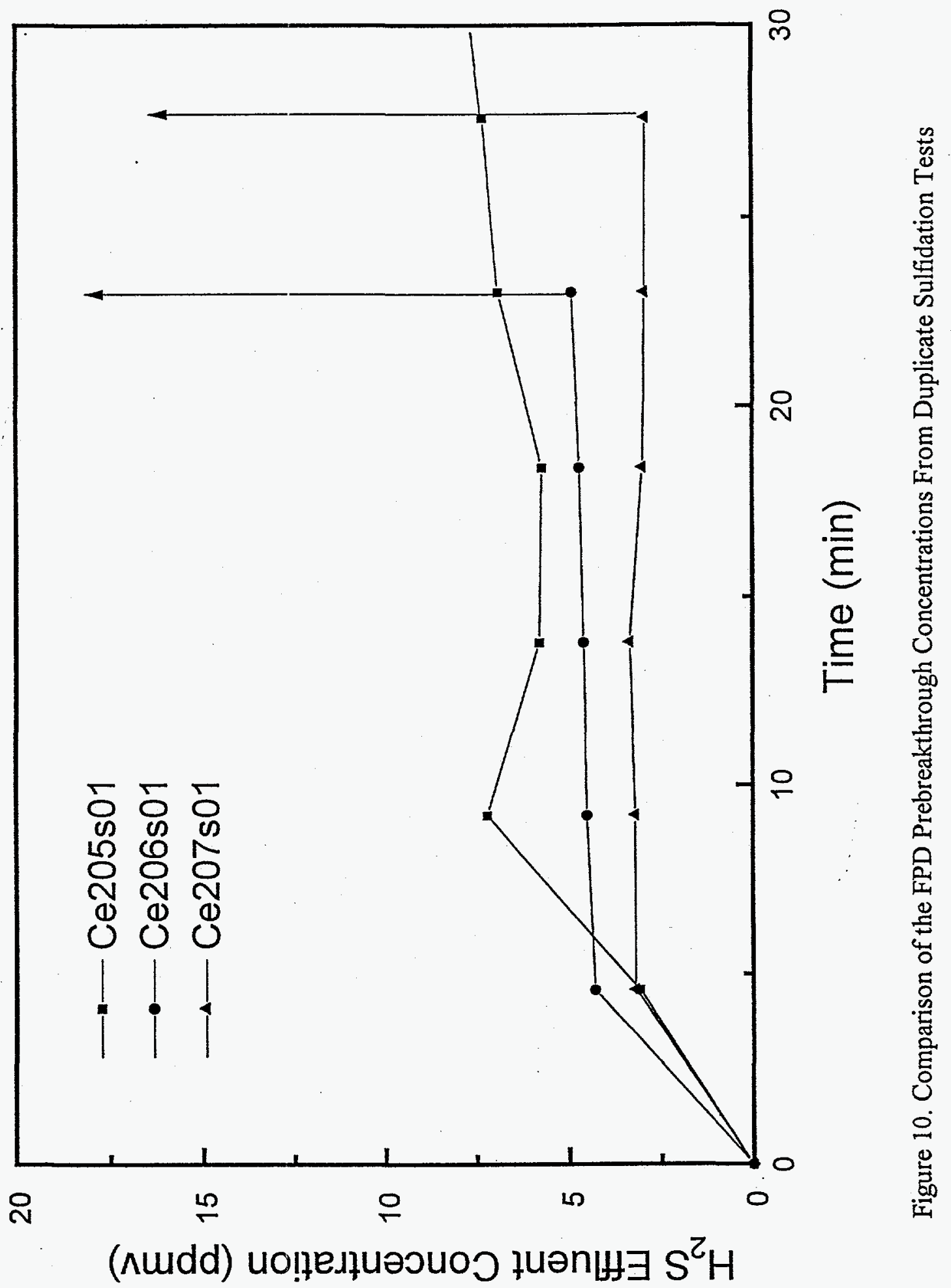


Figure 11 shows the complete $\mathrm{H}_{2} \mathrm{~S}$ breakthrough curves from Ce205s01 and Ce206s01 including both FPD and TCD results. Except for the large difference in the time and slope of the FPD breakthrough the results are quite similar. The data gap in both tests is associated with switching product gas flow to the TCD and providing sufficient time for that detector to equilibrate. In both runs there appears to be a second $\mathrm{H}_{2} \mathrm{~S}$ concentration plateau in the 100 to $300 \mathrm{ppmv}$ level which lasts for approximately 80 minutes. Major $\mathrm{H}_{2} \mathrm{~S}$ breakthrough then occurred in the 80 to 105 minute time span in both tests. This second concentration plateau and final breakthrough time correspond, at least qualitatively, to results of earlier runs in which only the TCD was used.

The Effect of Temperature

Tests $\mathrm{Ce} 207 \mathrm{~s} 01$ through $\mathrm{Ce} 212 \mathrm{~s} 01$ examined the effect of reduction-sulfidation temperature in intervals of $50^{\circ} \mathrm{C}$ between 600 and $850^{\circ} \mathrm{C}$. Only the FPD was used so that only initial $\mathrm{H}_{2} \mathrm{~S}$ concentrations were obtained. Results from all tests except $\mathrm{Ce} 212 \mathrm{~s} 01$ at $600^{\circ} \mathrm{C}$ are shown in Figure 12. At this low temperature, the $\mathrm{H}_{2} \mathrm{~S}$ concentration in all samples exceeded the FPD saturation limit. In the remaining five tests, all initial concentrations were below $10 \mathrm{ppmv}$ and decreased with decreasing temperature from about $6 \mathrm{pmv}$ at $850^{\circ} \mathrm{C}$ to less than $1 \mathrm{ppmv}$ at both 650 and $700^{\circ} \mathrm{C}$. This decrease in concentration with decreasing temperature is consistent with the sulfidation reaction being exothermic and equilibrium being closely approached. At $600^{\circ} \mathrm{C}$, the kinetics of the reaction becomes too slow for equilibrium to be approached. As previously described, the GC-FPD operating conditions are such that the $\mathrm{H}_{2} \mathrm{~S}$ analysis becomes increasingly uncertain as the $\mathrm{H}_{2} \mathrm{~S}$ concentration approaches and goes below 1 ppmv.

It is of interest to note that the prebreakthrough concentrations shown in Figure 12 compare quite well to previously published results from Meng and Kay (1987) at higher temperature. This is illustrated in Figure 13 where $\mathrm{H}_{2} \mathrm{~S}$ concentrations from the third sample of each of the Figure 12 tests have been added to previously reported data. While the feed gas composition used by Meng and Kay and in this study are different, and both are different from the Shell gas composition used to establish thermodynamic limits, the results are quite similar.

The importance of the prereduction step prior to sulfidation must be emphasized. The thermodynamics of the reaction between $\mathrm{H}_{2} \mathrm{~S}$ and substoichiometric $\mathrm{CeO}_{\mathrm{n}}(\mathrm{n}<2)$ are more favorable than the $\mathrm{H}_{2} \mathrm{~S}-\mathrm{CeO}_{2}$ reaction. This was proven in test $\mathrm{Ce} 213 \mathrm{~s} 01$ at $700^{\circ} \mathrm{C}$ where the prereduction step was omitted. Instead of the approximately $1 \mathrm{ppmv} \mathrm{H}_{2} \mathrm{~S}$ levels formed in Ce210s01 (See Figure 12), all $\mathrm{H}_{2} \mathrm{~S}$ concentrations from Ce213s 01 were above the FPD saturation limit.

The Effect of Feed Gas Composition

In tests in which the feed gas contained $1 \% \mathrm{H}_{2} \mathrm{~S}$ such as shown in Figure 12, FPD breakthrough occurred in less than 30 minutes and the $\mathrm{H}_{2} \mathrm{~S}$ concentration increased from low levels $(<10 \mathrm{ppmv})$ to above the FPD saturation limit in a single cycle. In order to extend the duration of 


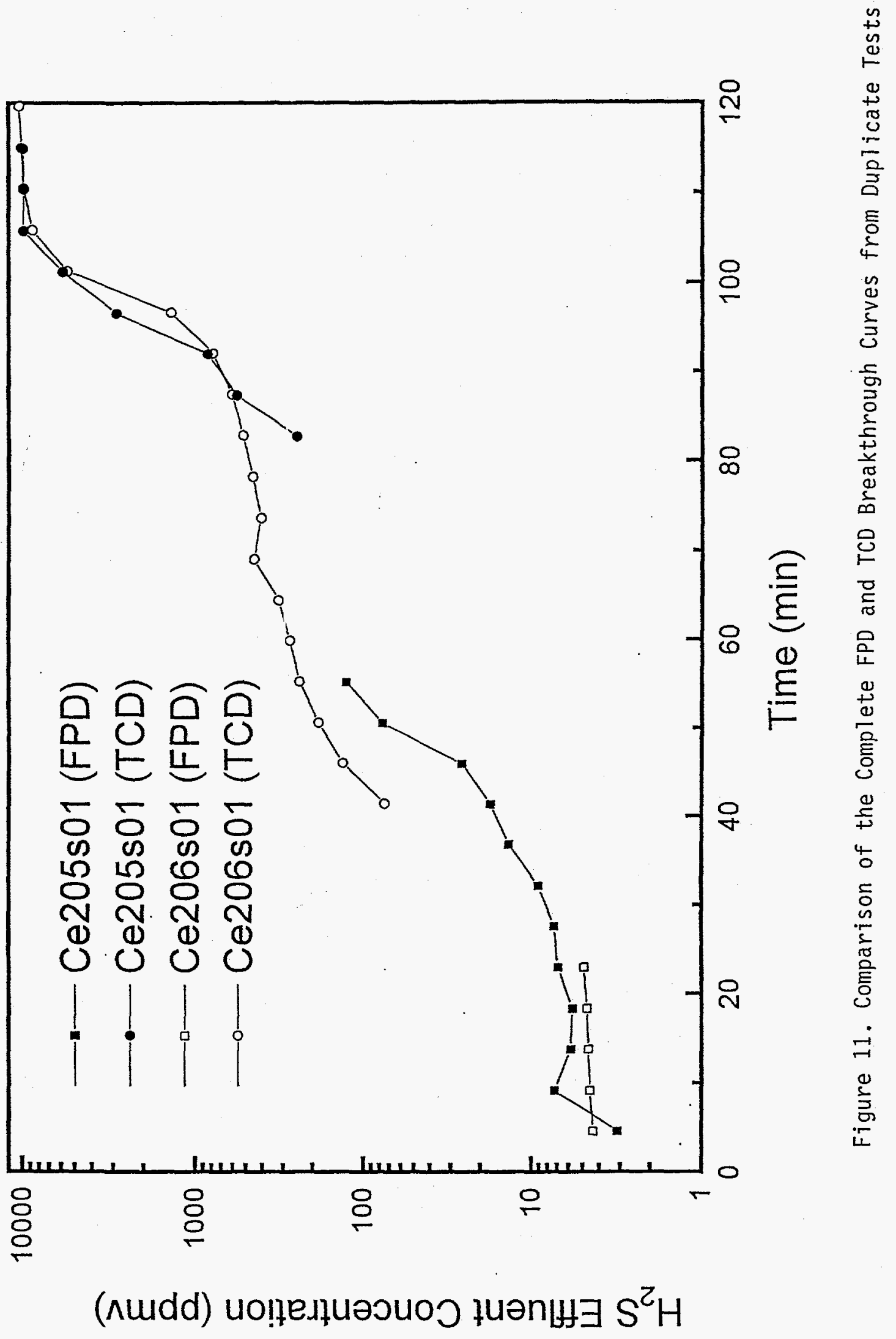




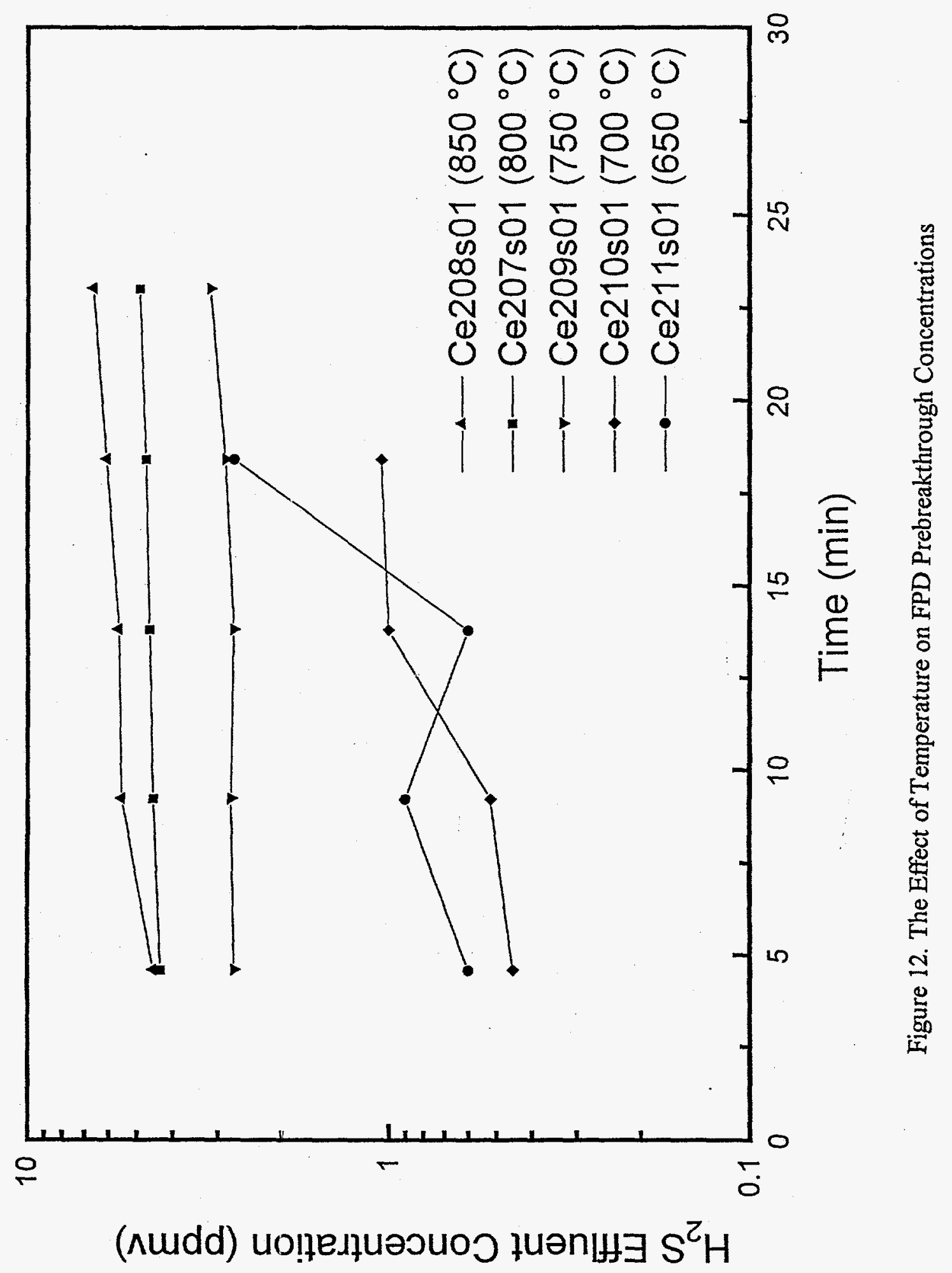




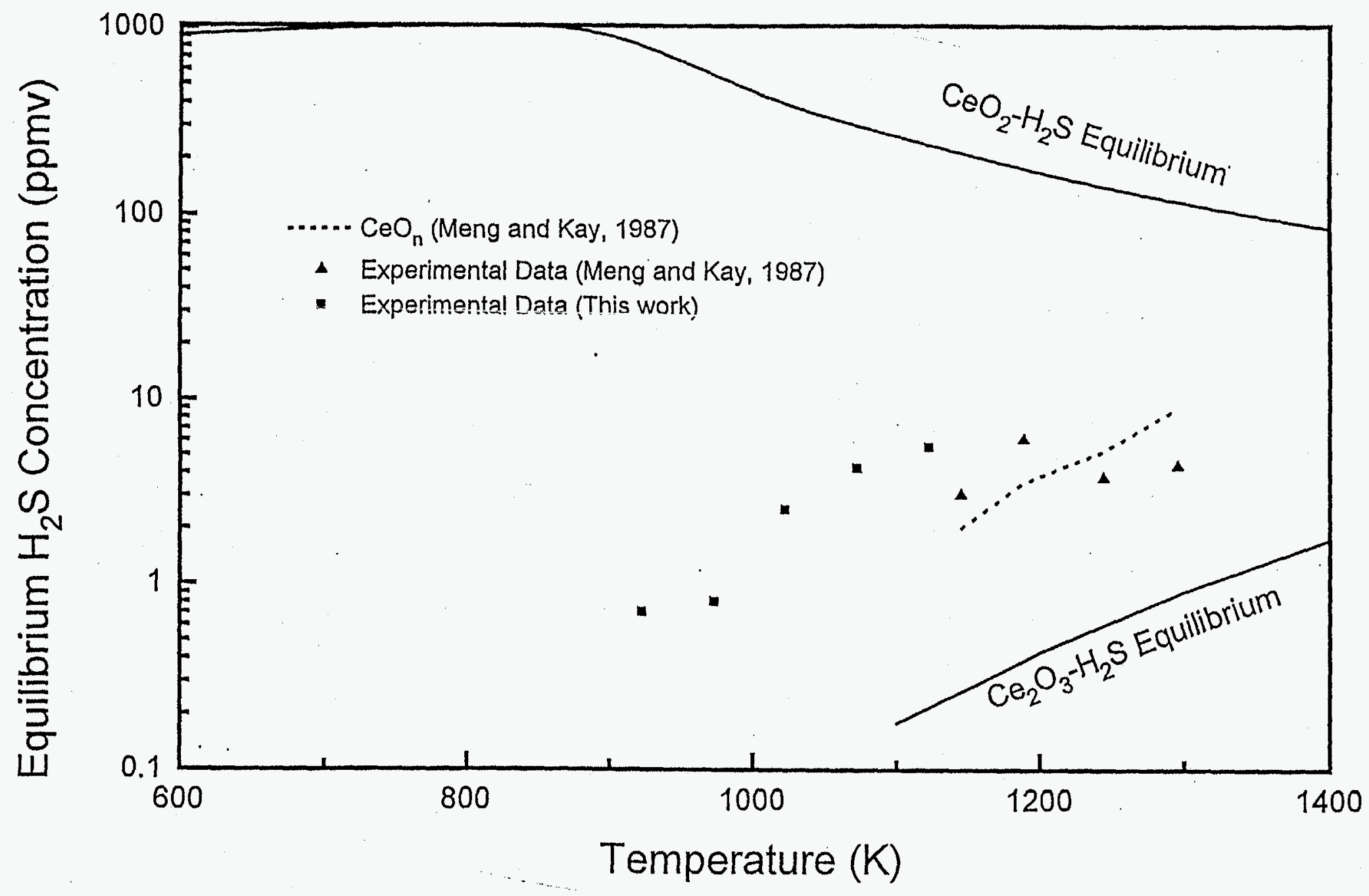

Figure 13. Comparison of FPD Prebreakthrough Concentrations From This Work With Earlier Results From Meng and/Kay 
the FPD prebreakthrough period and, hopefully, to obtain more information on the shape of the breakthrough curve, the concentration of $\mathrm{H}_{2} \mathrm{~S}$ in the feed gas was reduced by a factor of 4 to $0.25 \%$ in tests $\mathrm{Ce} 214 \mathrm{~s} 01$ and $\mathrm{Ce} 215 \mathrm{~s} 01$. Reaction conditions in these tests were the same except that only the FPD was used in $\mathrm{Ce} 214 \mathrm{~s} 01$ and both the FPD and TCD were used in Ce215s01. Also reaction conditions in these tests were the same as in Ce210s01 except that the feed gas contained $1 \% \mathrm{H}_{2} \mathrm{~S}$ in the latter case.

$\mathrm{H}_{2} \mathrm{~S}$ breakthrough curves from these runs are compared in Figure 14. An approximate correction for the increased $\mathrm{H}_{2} \mathrm{~S}$ feed concentration in $\mathrm{Ce} 210 \mathrm{~s} 01$ has been made by multiplying each sample time in that run by 4 . Initial concentrations from all tests are at the 1 ppmv level or less. FPD breakthrough from $\sim 1$ ppmv to 100 ppmv occurred at approximately 120 minutes in both Ce214s01 and $\mathrm{Ce} 215 \mathrm{~s} 01$. FPD breakthrough appeared to occur at an earlier time in $\mathrm{Ce} 210 \mathrm{~s} 01$ but the factor of 4 used to adjust the reaction time in this test is at best approximate.

The FPD results from $\mathrm{Ce} 214 \mathrm{~s} 01$ and $\mathrm{Ce} 215 \mathrm{~s} 01$ show a secondary plateau in the 100 to 300 ppmv level. TCD results from $\mathrm{Ce} 215 \mathrm{~s} 01$ show that this plateau lasted until about 400 minutes when final breakthrough to $2500 \mathrm{ppmv} \mathrm{H}_{2} \mathrm{~S}$ occurred. FPD concentrations above $100 \mathrm{ppmv}$ for both $\mathrm{Ce} 214 \mathrm{~s} 01$ and $\mathrm{Ce} 215 \mathrm{~s} 01$ must be treated cautiously as they are above the nominal saturation level and were estimated by extrapolation. Similarly, the TCD concentrations from Ce215s01 near 100 ppmv should be treated with caution as they are near the lower detection limit of the TCD. Thus the apparent concentration decrease in $\mathrm{Ce} 215 \mathrm{sOl}$ following the switch from the FPD to the TCD may be attributed to analytic uncertainty.

The Effect Of Volumetric Feed Rate

The effect of volumetric feed rate at 200,400 , and $800 \mathrm{sccm}$ was investigated at $700^{\circ} \mathrm{C}$ using feed concentrations of both $1 \%$ and $0.25 \% \mathrm{H}_{2} \mathrm{~S}$. However, prior to these reaction tests a series of nonreacting tracer tests was completed so that appropriate delay time corrections as a function of flow rate could be made. Delay time is defined as the time interval between opening the valve to feed reactive gases and those gases reaching the sorbent bed.

Results of the tracer tests are presented in Figure 15. The $\mathrm{H}_{2} \mathrm{~S}$ concentrations in the feed and product gases were effectively equal in the third sample $(\sim 10 \mathrm{~min})$ at $200 \mathrm{sccm}$, in the second sample $(\sim 7 \mathrm{~min})$ at $400 \mathrm{sccm}$, and in the first sample $(\sim 3 \mathrm{~min})$ at $800 \mathrm{sccm}$. Delay time, $t_{D}$, was estimated by numerically intergrating the area above the breakthrough curve and converting that area to a rectangle of the same area with height equal to the $\mathrm{H}_{2} \mathrm{~S}$ feed concentration and width equal to $t_{D}$. Resultant values of $t_{D}$ at the three flow rates are:

$\begin{array}{ll}200 \mathrm{sccm} & t_{D}=5.5 \mathrm{~min} \\ 400 \mathrm{sccm} & t_{D}=2.4 \mathrm{~min} \\ 800 \mathrm{sccm} & t_{D}=1.2 \mathrm{~min}\end{array}$




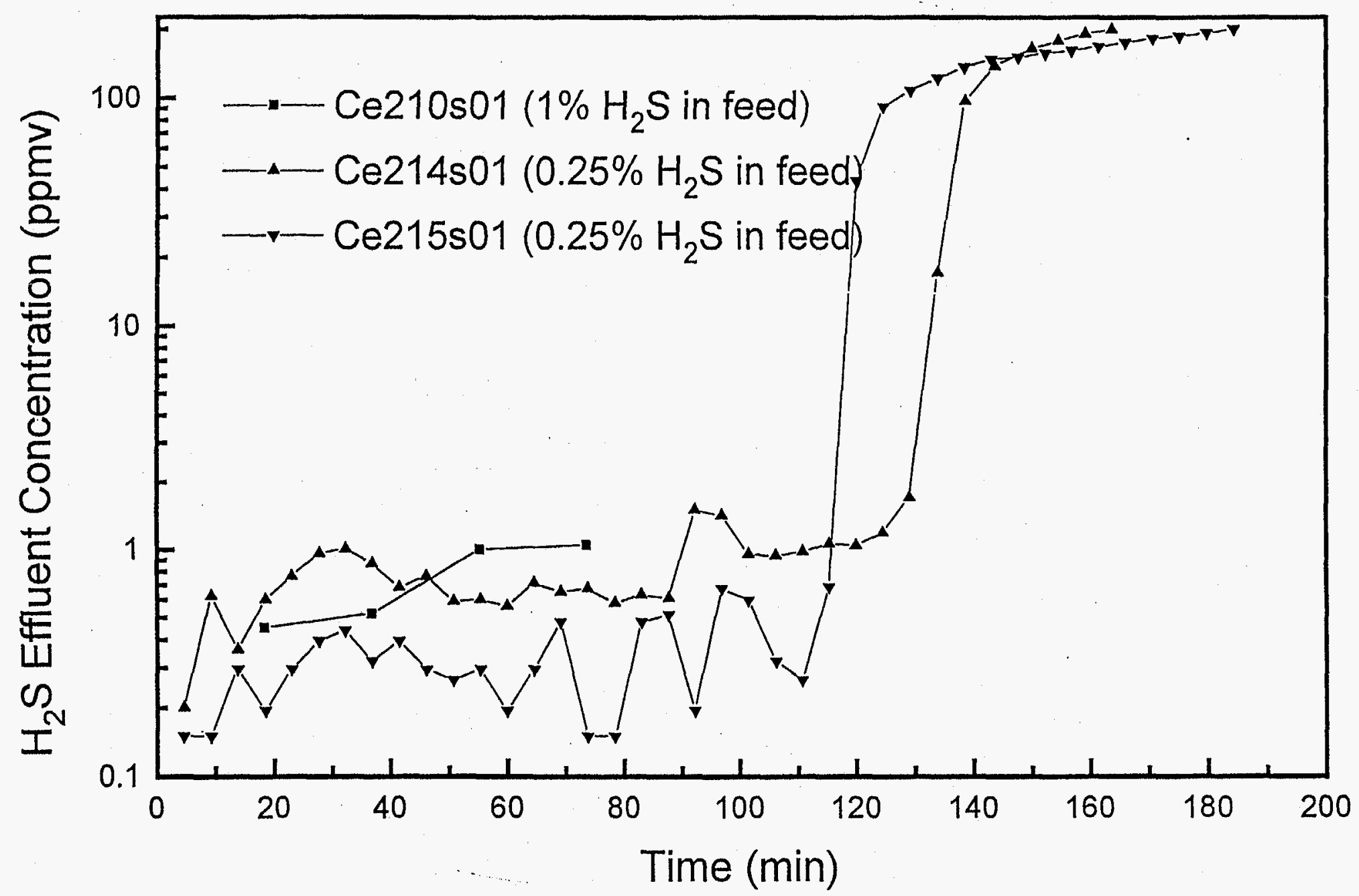

Figure 14. The Effect of $\mathrm{H}_{2} \mathrm{~S}$ Feed Composition on FPD Prebreakthrough Concentrations 


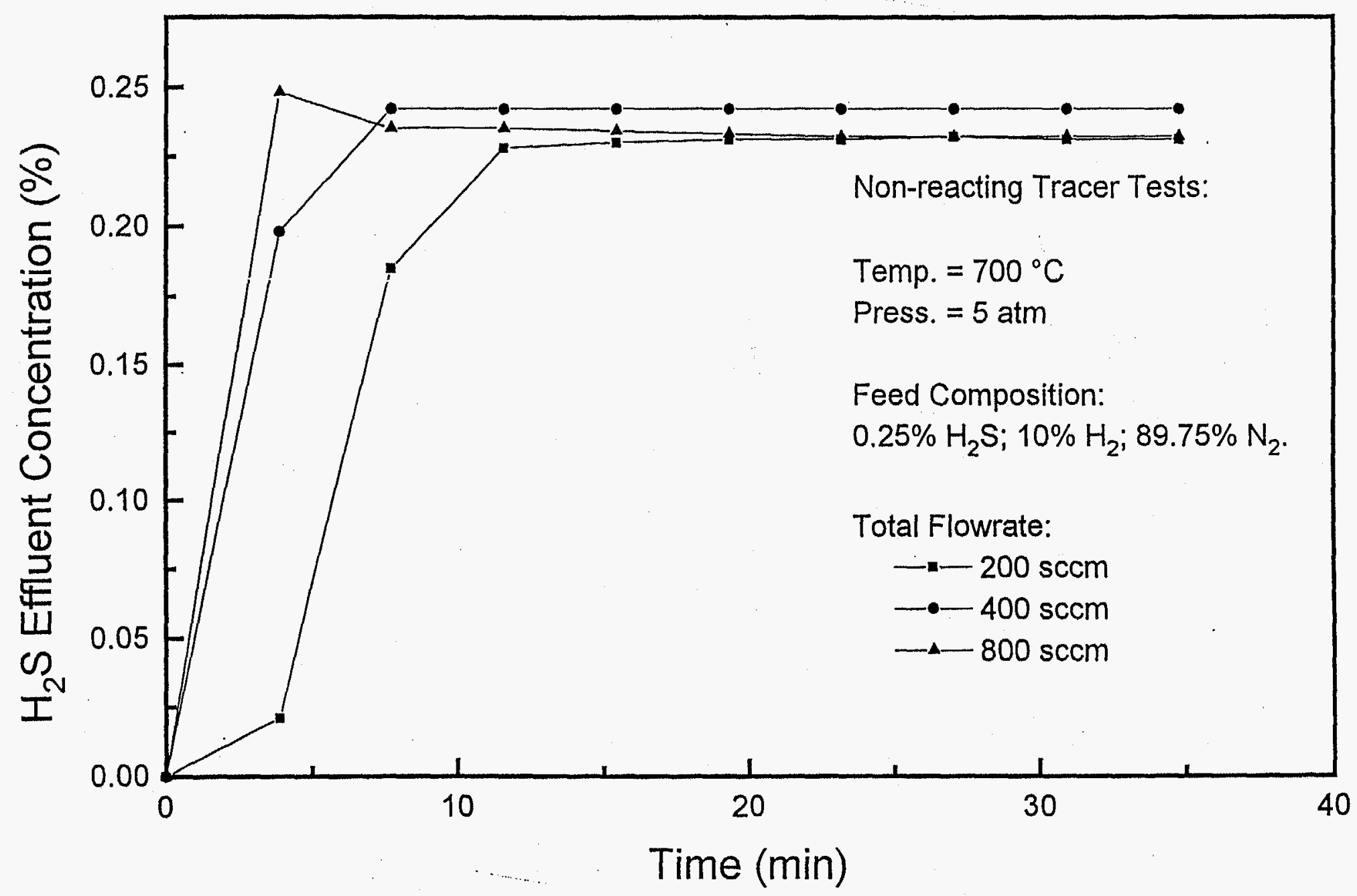

Figure 15. Nonreacting Tracer Test Results as a Function of Volumetric Feed Rate 
FPD prebreakthrough concentrations of $1 \mathrm{ppmv}$ or less were achieved in all tests with breakthrough generally occurring earlier at the larger feed rates. FPD results from the three tests using $0.25 \% \mathrm{H}_{2} \mathrm{~S}$ in the feed gas ( $\mathrm{Ce} 215 \mathrm{~s} 01, \mathrm{Ce} 218 \mathrm{~s} 01$, and $\mathrm{Ce} 219 \mathrm{~s} 01$ ) are shown as a function of dimensionless time in Figure 16. Dimensionless time, $\mathrm{t}^{*}$, is defined as

$$
\mathfrak{t}^{*}=\frac{t-t_{D}}{t_{E}}
$$

$t_{D}$ is the delay time and $t_{E}$ is the theoretical time at which all $\mathrm{CeO}_{2}$ would be converted to $\mathrm{Ce}_{2} \mathrm{O}_{2} \mathrm{~S}$ with complete removal of $\mathrm{H}_{2} \mathrm{~S}$. When $\mathrm{H}_{2} \mathrm{~S}$ removal is essentially complete, as it is for all of the data in Figure 16, the value of $t^{*}$ is effectively equal to the fractional conversion of $\mathrm{CeO}_{\mathrm{n}}$ to $\mathrm{Ce}_{2} \mathrm{O}_{2} \mathrm{~S}$. From the figure we see that FPD breakthrough begins at $\mathrm{t}^{*} \sim 0.17$ at $800 \mathrm{sccm}, 0.31$ at 400 , and 0.32 at 200 $\mathrm{sccm}$. However, at $200 \mathrm{sccm}$ the $\mathrm{H}_{2} \mathrm{~S}$ concentration remained below 10 ppmv until $\mathrm{t}^{*} \sim 0.41$.

FPD breakthrough occurred much sooner in the tests using $1 \% \mathrm{H}_{2} \mathrm{~S}$ in the feed gas and severely limited the amount of data which could be obtained prior to FPD saturation. This was particularly true in test $\mathrm{Ce} 217 \mathrm{~s} 01$ at $800 \mathrm{sccm}$ where only two samples were obtained prior to breakthrough. Results from Ce213s $01, \mathrm{Ce} 216 \mathrm{~s} 01$, and $\mathrm{Ce} 217 \mathrm{~s} 01$ all at $700^{\circ} \mathrm{C}$ at $5 \mathrm{~atm}$ are compared on a dimensionless time basis in Figure 17. Dimensionless times corresponding to the last sample in which the $\mathrm{H}_{2} \mathrm{~S}$ concentration was near 1 ppmv decreased from $\mathrm{t}^{*} \sim 0.31$ at $200 \mathrm{sccm}$ to $\mathrm{t}^{*} \sim 0.18$ at both 400 and $800 \mathrm{sccm}$. There is, however, a reasonably large uncertainty in the last two values because, between samples, $\Delta t^{*} \sim 0.09$ at $800 \mathrm{sccm}$ and $\Delta t^{*} \sim 0.045$ at $400 \mathrm{sccm}$.

\section{CONCLUSIONS}

With the more sensitive FPD, we have shown that initial $\mathrm{H}_{2} \mathrm{~S}$ concentrations in the range of 1 to $10 \mathrm{ppmv}$ can be achieved over a temperature range of 650 to $850^{\circ} \mathrm{C}$. The key to achieving the low prebreakthrough concentration is the prereduction step in which $\mathrm{CeO}_{2}$ is reduced to $\mathrm{CeO}_{\mathrm{n}}(\mathrm{n}<2)$. The prereduction requirement was proven by comparing initial $\mathrm{H}_{2} \mathrm{~S}$ concentrations at $700^{\circ} \mathrm{C}$ with and without prereduction. In the former case initial $\mathrm{H}_{2} \mathrm{~S}$ concentrations were about $1 \mathrm{ppmv}$ and in the latter case all $\mathrm{H}_{2} \mathrm{~S}$ concentrations exceeded the saturation limit of the FPD $(\sim 100 \mathrm{ppmv})$. At $600^{\circ} \mathrm{C}$ even with a prereduction step the $\mathrm{H}_{2} \mathrm{~S}$ concentration always exceeded FPD saturation. This may be attributed to lack of reduction and/or slow sulfidation kinetics at the lower temperature.

The low initial $\mathrm{H}_{2} \mathrm{~S}$ concentrations were achieved using feed concentrations ranging from 0.25 to $1.0 \% \mathrm{H}_{2} \mathrm{~S}$ and flow rates from 200 to $800 \mathrm{sccm}$. Of course the duration of the FPD prebreakthrough period decreased as both the inlet concentration and feed rate increased. In the most favorable case with a feed rate of $200 \mathrm{sccm}$ and $0.25 \% \mathrm{H}_{2} \mathrm{~S}$, the $\mathrm{H}_{2} \mathrm{~S}$ concentration in the product remained below $20 \mathrm{ppmv}$ until approximately $40 \%$ of the sorbent was converted to $\mathrm{Ce}_{2} \mathrm{O}_{2} \mathrm{~S}$. 


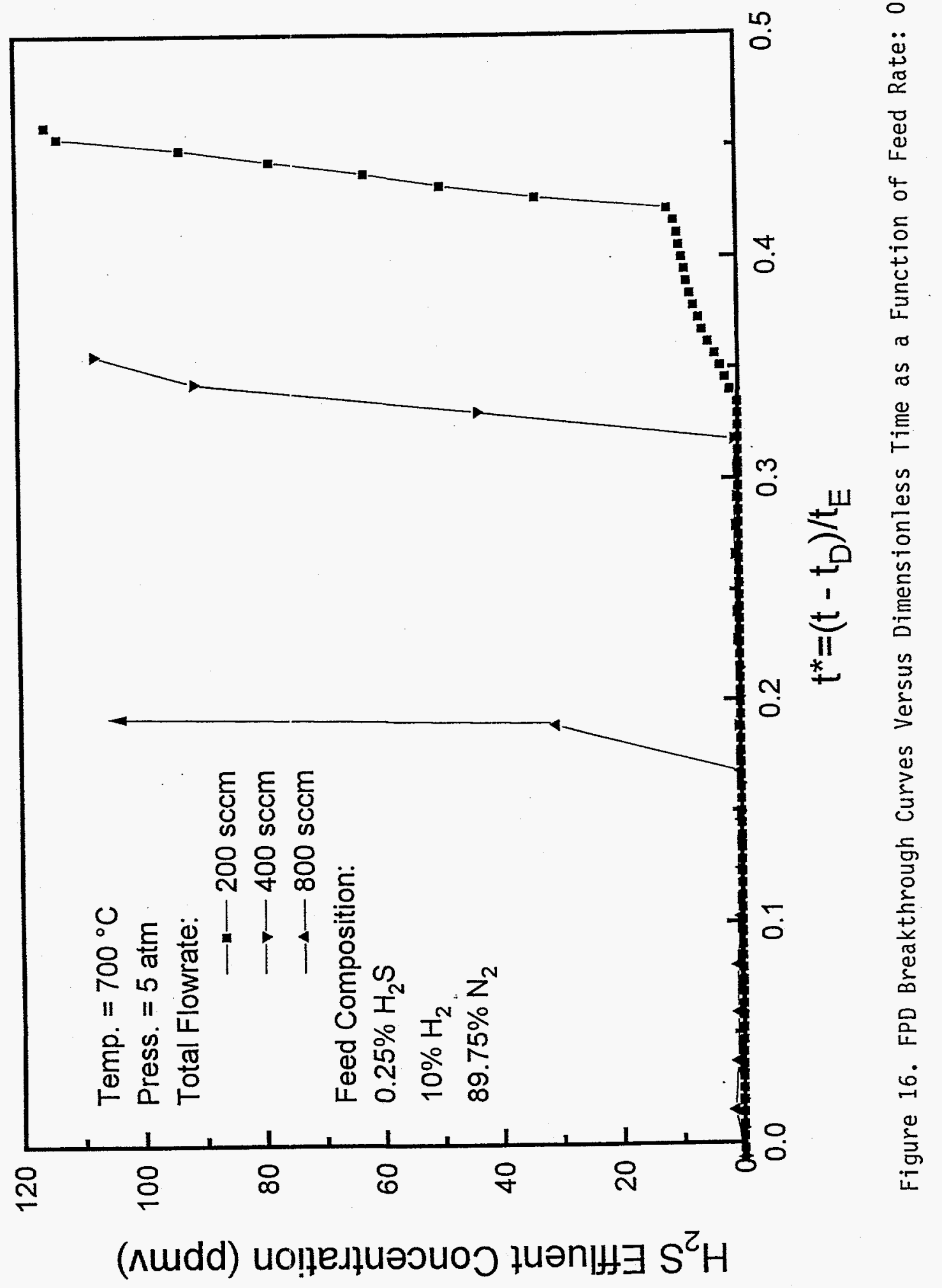




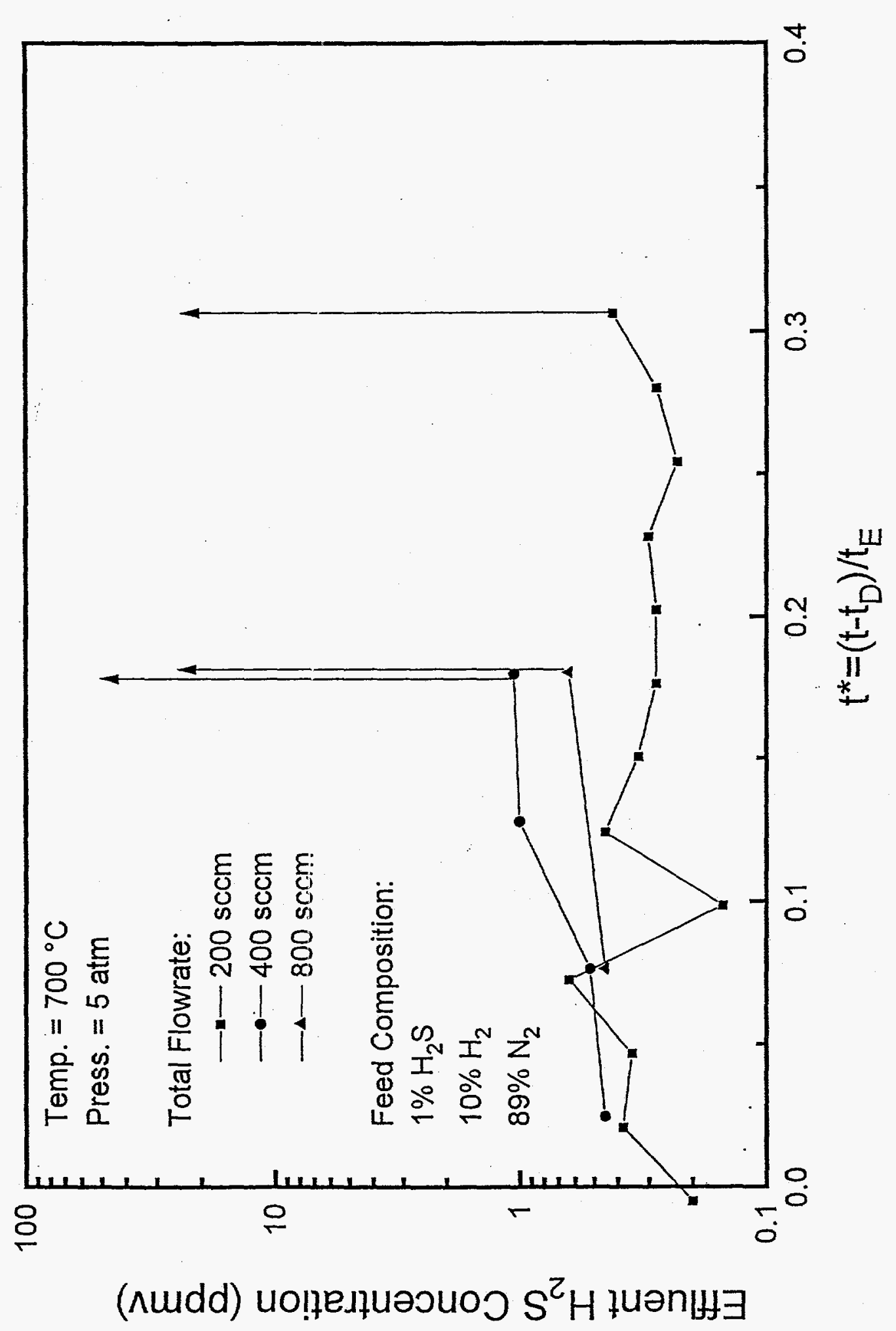

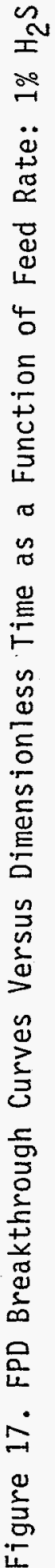

